\title{
Avaliação da Qualidade de Pintado Amazônico (Pseudoplatystoma Fasciatum X Leiarius Marmoratus) Eviscerado e Estocado em Gelo
}

\author{
Marilu Lanzarin (IV,V,VI), Daniel Oster Ritter (IV,V,VI), Edivaldo \\ Sampaio de Almeida Filho (V), Eliane Teixeira Mársico (IV), Mônica \\ Queiroz de Freitas (IV) \\ (IV) UFF - Universidade Federal Fluminense (Vital Brazil Filho, nำ4, Niterói, RJ), (V) UFMT - \\ Universidade Federal de Mato Grosso (Avenida Fernando Corrêa da Costa, №2367, Cuiabá, \\ MT), (VI) IFMT - Instituto Federal de Mato Grosso Campus Sorriso (Avenida Tancredo Neves, \\ Sorriso, MT)
}

\section{Resumo}

A importância do pescado na alimentação tem demonstrado tendência ao crescimento e destaque frente ao mercado consumidor em função do reconhecimento do seu alto valor nutritivo, fácil digestibilidade e fonte expressiva de ácidos graxos da série ômega, porém, trata-se um uma matriz alimentar de alta perecibilidade. Objetivou-se a partir desse estudo criar subsídio científico para avaliação da qualidade de pintado amazônico (P. fasciatum X L. marmoratus) associando resultados bacteriológicos e físicoquímicos. Os exemplares de aproximadamente $2,0 \mathrm{~kg}$ obtidos de pisciculturas foram abatidos por hipotermia e encaminhados ao laboratório, no qual foram eviscerados e estocados em caixas isotérmicas contendo gelo em escamas na proporção $1: 1$ gelo/peixe, mantendo a temperatura de $0^{\circ} \mathrm{C}$ $+/-1^{\circ} \mathrm{C}$. No primeiro dia de estocagem foi realizada a quantificação de bactérias heterotróficas aeróbias mesófilas (BHAM), bactérias heterotróficas aeróbias psicrotróficas (BHAP), bactérias do gênero Aeromonas, determinação do potencial hidrogeniônico $(\mathrm{pH})$ e quantificação de bases voláteis totais (BVT), sendo estas repetidas a cada dois dias durante 28 dias de estocagem. As análises foram realizadas em triplicata totalizando 45 unidades amostrais e os resultados foram

\footnotetext{
Referência:

Marilu Lanzarin, Daniel Oster Ritter, Edivaldo Sampaio de Almeida Filho, Eliane Teixeira Mársico, Mônica Queiroz de Freitas. Avaliação da Qualidade de Pintado Amazônico (Pseudoplatystoma Fasciatum X Leiarius Marmoratus) Eviscerado e Estocado em Gelo. In: Anais do 12을 Congresso Latinoamericano de Microbiologia e Higiene de Alimentos - MICROAL 2014 [= Blucher Food Science Proceedings, num.1, vol.1]. São Paulo: Editora Blucher, 2014.

DOI $10.5151 /$ foodsci-microal-223
} 
compilados e submetidos à análise estatística. A contagem de BHAM variou de 3,53 a 16,19 log UFC/g durante estocagem, sendo que a alta contagem encontrada no primeiro dia de estocagem e subsequentes pode ser explicada pelo fato de os peixes de águas tropicais apresentarem uma carga microbiológica rica em bactérias mesófilas devido ao seu habitat e temperatura das águas. A temperatura de estocagem $\left(0^{\circ} \mathrm{C}\right)$ também demonstrou ser um dos principais fatores de seleção o que permitiu o desenvolvimento de bactérias psicrotróficas com variação de 3,09 a 13,04 $\log$ UFC/g durante estocagem. Além disso, em virtude do seu caráter ubíquo, bactérias do gênero Aeromonas sp. podem ser encontradas em diferentes habitats, sobretudo em águas, sendo assim esta bactéria pode estar presente em peixes se multiplicando em temperaturas normalmente utilizadas na estocagem, fato observado neste estudo com contagens variando de 1,82 a 11,43 log UFC/g durante estocagem. Como resultado do metabolismo bacteriano de componentes químicos do peixe, são produzidos compostos voláteis que ocasionam a elevação do pH e BVT, sendo que o aumento no $\mathrm{pH}$ e BVT pode ser observado neste estudo ao longo do período de estocagem e acompanhando as alterações bacteriológicas, com valores entre 6,11 a 6,63 para o $\mathrm{pH}$ e 9,45 a 13,37 $\mathrm{mgN} / 100 \mathrm{~g}$ para BVT. Neste estudo pode-se observar que as contagens bacteriológicas, assim como as determinações físico-químicas tiveram correlação positiva com o processo de deterioração do peixe, sendo que todas apresentaram um aumento significativo em relação ao tempo de estocagem em gelo sendo então considerados bons parâmetros para verificação da qualidade do peixe.

Palavras-Chave: Frescor, Peixes dulcícolas, Qualidade, Validade Comercial Agência de Fomento: $\mathrm{CNPq}$ 